\title{
CHARACTERIZATION OF Cu10wt.\%AI INTERMETALLIC COATINGS APPLIED BY THE ATMOSPHERIC PLASMA SPRAYING PROCESS
}

\author{
Mihailo R. Mrdak \\ Research and Development Center IMTEL Communications a.d., \\ Belgrade, Republic of Serbia, \\ e-mail: drmrdakmihailo@gmail.com, \\ ORCID iD: (ibhttp://orcid.org/0000-0003-3983-1605
}

DOI: 10.5937/vojtehg64-10688

FIELD: Chemical Technology

ARTICLE TYPE: Original Scientific Paper

ARTICLE LANGUAGE: English ${ }^{1}$

\section{Summary:}

The atmospheric plasma spray process is one of the procedures used for the deposition of coatings resistant to wear due to friction, erosion, cavitation and corrosion. In this paper, the APS process produced a Cu10wt.\%Al intermetallic coating which is a reliable candidate for use in tribological environments because of a combination of low price and exceptional resistance to abrasion under different work conditions. The aim of this study was to investigate the mechanical properties and the structure of the Cu10wt.\%Al intermetallic coating and develop an efficient method for repairing and improving light alloy resistance to wear. Many components of copper alloys tend to be degraded due to corrosive environment, friction, erosion and cavitation. Such components can be saved by surface engineering with the use of appropriate coatings on surface areas exposed to degradation. A typical microstructure of a coating for the APS process is lamellar, with micro pores, unmelted particles, interlamellar oxides and precipitates present in it. The mechanical properties of Cu10wt.\% Al coatings were investigated by measuring the microhardness of coating layers using the $\mathrm{HV}_{0.3}$ method while the

ACKNOWLEDGEMENT: The author is thankful for the financial support from the Ministry of Education and Science of the Republic of Serbia (national project TR 34016). 
bond strength was tested on a tensile machine. The morphologies of powder particles and the coating surfaces were analyzed on a scanning electron microscope (SEM). The analysis of the coating microstructure was carried out with the use of an optical microscope, and a share of micro pores was determined by analyzing the micrographs through an optical microscope (OM).

Key words: wearing, intermetallics, erosion, corrosion, coatings, cavitation, Al, abrasives.

\section{Introduction}

APS - atmospheric plasma spraying is one of the technological processes used to manufacture coatings with a thickness between 0.1 and $0.5 \mathrm{~mm}$. Plasma spray technology is one of possible solutions to produce copper-based coatings because of afordable production costs and possibilities to produce coatings on parts of complex shapes. The APS process includes the injection of powder particles into a plasma jet, its melting or semi-melting, and then accelerating and collision with the substrate where powder particles are deposited, forming a coating (Mrdak, 2015a, pp.137-159), (Mrdak, 2015b, pp.46-67). The microstructure of plasma spray coatings is characterized by a lamellar structure with limited inter-lamellar bonding due to the presence of micro pores. The coating microstructure and its mechanical properties are influenced by a large number of process parameters which directly affect the phase composition and porosity content for a specific powder and a range of powder particles (Mrdak, et al., 2015, pp.337-343), (Mrdak, 2016a, pp.1-25), (Mrdak, 2016b, pp.411-430), (Vencl, et al., 2011, pp.1281-1288), (Vencl, et al., 2010, pp.591-604). Copper is a metal that is widely used in many applications because of its excellent thermal and electrical conductivity. The mechanical properties of copper can be improved by alloying. Some copper alloys such as $\mathrm{Cu}-\mathrm{Al}, \mathrm{Cu}-\mathrm{Si}$ and $\mathrm{Cu}-$ $\mathrm{Al}-\mathrm{Fe}$ are used for wider industrial applications, because they are quite resistant to wear and corrosion. Cu10wt.\%Al alloys are widely used in the chemical industry thanks to their high corrosion resistance. In this alloy type, besides the $\alpha$ structure, there is the $\beta$ structure as well. Wear resistant Cu10wt.\%Al coatings are used on working parts to reduce damage due to friction, erosion, corrosion and cavitation (Bartuli, et al., 2007, pp.175-185). Cu-Al intermetallic coatings are good candidates for use in tribological environments because of a combination of low prices and exceptional resistance to abrasion under different work conditions. Optimum protection against wear of light metal substrates can be provided with effective application of thermal spray processes for coating 
and powder depending on the working environment and working conditions (Sartale, Yoshitake, 2010, pp.353-360), (Wang, Seitz, 2001, pp.755-761). Intermetallic coatings or metal-ceramic composite coatings can be obtained by thermal spray powder spraying. Cu-Al intermetallic systems have been actively researched for use in aircraft, automotive, marine, construction, etc. The Cu-Al system have long been used for wheel bearings for planes and screws for ships because of its resistance to wear and corrosion (Sartale, Yoshitake, 2010, pp.353-360). Cu10wt.\%Al powder marked Metco 445 is mechanically coated aluminum bronze which shows self-bonding for substrates during the thermal spray process as a result of the chemical reaction of the coated components which build intermetallic phases. The powder contains aluminum from 7.0 to $12.0 \mathrm{wt} \% \mathrm{Al}$ (Material Product Data Sheet Aluminum Bronze Thermal Spray Powders Thermal Spray Powder Products Metco 445, 2012, DSMTS-0103.0, Sulzer Metco). Coatings have good resistance to friction and scuffing at low and moderate temperatures and excellent resistance to abrasion and cavitation. Testing of Cu10wt.\%Al coatings to abrasive wear and sliding wear using the ringon-disk method and a load of $150 \mathrm{~g}$ over the sliding speed of $4.5 \mathrm{~cm} / \mathrm{s}$ showed that the abrasive coating wear is $0.52 \mathrm{mgm}^{-1}$, and that sliding wear is $2.8 \times 10^{-5} \mathrm{~mm}^{3} \mathrm{~m}^{-1}$. The main coating wear mechanism is plastic deformation (Limpichaipanit, et al., 2011, pp.123-126). Coatings machine easily and excellently. Typical components covered by Cu10wt.\%Al coatings are: supports of bearings, sleeves of hydraulic presses, piston guides, air compressor seals, water pumps, turbine nozzles, etc. The presence of aluminum in bronze increases the resistance of the coating to corrosion because of the formation of a thin cohesive surface oxide which acts as a protective layer on the alloy rich in copper (Material Product Data Sheet Aluminum Bronze Thermal Spray Powders Thermal Spray Powder Products Metco 445, 2012, DSMTS-0103.0, Sulzer Metco). To understand better the reaction processes which occur between $\mathrm{Cu}$ and $\mathrm{Al}$ during the process of powder melting and the formation of intermetallic phases, it is necessary to know the Cu-Al equilibrium diagram. In the equilibrium phase diagram of $\mathrm{Cu}-\mathrm{Al}$, there are five stable intermetallic phases, i.e.: $\mathrm{Cu}_{9} \mathrm{Al}_{4}, \mathrm{Cu}_{3} \mathrm{Al}_{2}, \mathrm{Cu}_{4} \mathrm{Al}_{3}, \mathrm{CuAl}$ and $\mathrm{CuAl}_{2}$ with two solid solutions $\mathrm{Cu}(\mathrm{Al})$ which are often described as $\alpha-\mathrm{Cu}$ and $\mathrm{Al}(\mathrm{Cu})$ (ASM Handbook, 1992, Volume 3, Alloy Phase Diagrams, ASM International, Metals Park). Studies have shown that in the process of powder melting in plasma, due to the reaction of $\mathrm{Al}$ and $\mathrm{Cu}$, various intermetallic phases are formed, such as: $\mathrm{CuAl}_{2}, \mathrm{Cu}_{9} \mathrm{Al}_{4}, \mathrm{Cu}_{3} \mathrm{Al}_{2}, \mathrm{Al}_{4} \mathrm{Cu}_{9}$ (Altuncu, et al., 2012, pp.181-183). The main intermetallic phases which affect the wear resistance of the coating are $\mathrm{Cu}_{9} \mathrm{Al}_{4}$ and $\mathrm{Cu}_{3} \mathrm{Al}_{2}$. Plasma spray deposited Cu10wt.\%Al coatings have a lamellar structure, with 
present unmelted particles, precipitates, and inter-lamellar pores. According to the authors (Hang, et al., 2008, pp.416-424), (Li, Sun, 2004, pp.92-101) in the microstructure there are present intermetallic phases of $\mathrm{CuAl}_{2}$ and $\mathrm{Cu}_{9} \mathrm{Al}_{4}$. The alloy base is a solid solution of $\alpha-\mathrm{Cu}(90.6-100 \mathrm{wt} \% \mathrm{Cu})$ and $\beta-\mathrm{Cu}(85.0-91.5 \mathrm{wt} \% \mathrm{Cu})$. In the microstructure of the coating, there are not black oxide lamellae of $\mathrm{Al}_{2} \mathrm{O}_{3}$ oxide ( $\mathrm{Li}$, Sun, 2004, pp.92-101). Cu10wt.\%Al coatings consist of a bright phase of copper and a dark phase of copper oxide $\mathrm{Cu}_{2} \mathrm{O}$. Copper oxide is primarily formed when temperatures $\geq 1000{ }^{\circ} \mathrm{C}$ and in the presence of oxygen, which occurs when using the plasma spray process (Hang, et al., 2008, pp.416-424), (Li, Sun, 2004, pp.92-101).

In this paper, plasma spraying at atmospheric pressure was used to deposit an aluminum bronze coating which contains 7.0 to $12.0 \mathrm{wt} \% \mathrm{Al}$. The coating microstructure was analyzed with a light microscope and the coating surface was analysed with the SEM - scanning electron microscope. The aim of this study was to investigate the mechanical properties and the microstructure of the Cu10wt.\%Al intermetallic coating and to develop an economically efficient method of depositing intermetallic coatings for improving resistance of worn aircraft parts made of $\mathrm{Cu}$ alloys exposed to a combination of corrosion and wear.

\section{Materials and experimental details}

The material on which layers of Cu10wt.\%Al(7.0 to 12.0 wt\%Al) intermetallic coatings were deposited was made of stainless steel $\mathrm{X} 15 \mathrm{Cr} 13$ (EN 1.4024) in the thermally unprocessed state. Powder of the Sulzer Metco company labeled Metco 445 was used to produce the Cu10wt.\%Al coating. The powder was manufactured using mechanical coating and spheroidization to a specific granulation density of 3.1-4.3 $\mathrm{g} / \mathrm{cm}^{3}$. The powder melting point is $1040{ }^{\circ} \mathrm{C}$. Powder with granules in a range of $45-106 \mu \mathrm{m}$ was used for the experiment (Material Product Data Sheet Aluminum Bronze Thermal Spray Powders Thermal Spray Powder Products Metco 445, 2012, DSMTS-0103.0, Sulzer Metco). Figure 1 shows the (SEM) scanning electron photomicrographs of the Cu10wt.\% Al powder particles morphology. The powder particles are approximately spherical in shape. The testing of the mechanical properties of the Cu10wt.\% Al coating was done in accordance with the Pratt \& Whitney standard (Turbojet Engine - Standard Practices Manual (PN 582005), 2002, Pratt \& Whitney, East Hartford, USA). The bases on which were deposited layers of coatings for microhardness testing and evaluation of the microstructure in the deposited state are made of steel Č.4171 (X15Cr13 EN10027) in the thermally unprocessed state with the dimensions of $70 \times 20 \times 1.5 \mathrm{~mm}$. 


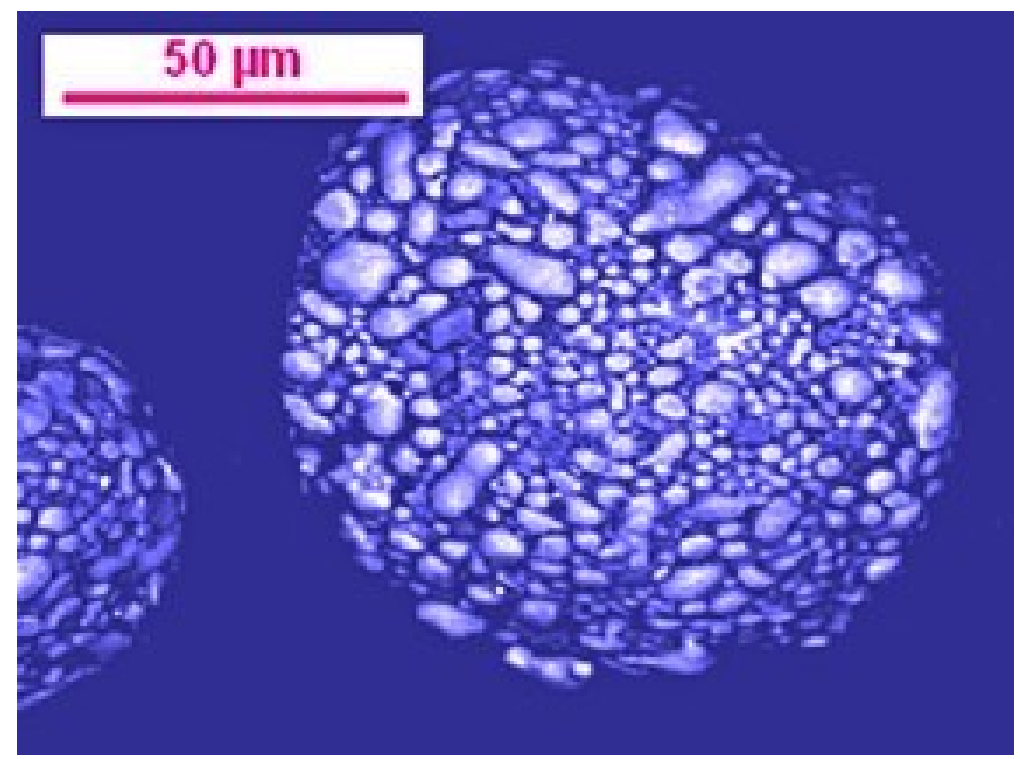

Figure 1 - (SEM) Scanning electron micrography of a Cu10wt.\%Al powder particle PUc. 1 - (SEM) Электронная микрография частиц порошка Cu10вес.\%Al

Slika 1 - Skening elektronska mikrografija (SEM) čestice praha Cu10tež.\%Al

The substrates for testing the bond strength are also made of steel C.4171 (X15Cr13EN10027) in the thermally unprocessed state with the dimensions of $\varnothing 25 \times 50 \mathrm{~mm}$. The microhardness of layers was tested using $\mathrm{HV}_{0.3}$ and bond strength tensile testing. The microhardness measurements were performed along the lamellae. Five readings of microhardness values of the layers were performed in the middle and at the ends of the samples while two extreme values were rejected. Out of three remaining values, the average value is shown. The bond strength was tested at room temperature with a tensile speed of $1 \mathrm{~cm} / 60 \mathrm{~s}$. Five specimens were tested, out of which two extreme values were rejected. Out of the three remaining values, the mean value of the bond strength is shown. The morphology of the powder particles and the surface of the deposited coating was examined using scanning electron microscopy (SEM). The microstructure of the deposited layers was examined on an optical microscope (OM). The share of micro pores in the coating was analysed by analysing 5 photos at 200x magnification. In this paper, the mean value of the share of micro pores in the coating is presented.

Cu10wt.\%Al powder is deposited with the atmospheric plasma spray system of the Plasmadyne company and the plasma gun SG-100, with controlled plasma spray parameters. The plasma gun SG-100 consists of a cathode type K1083-129, anode type A 2083-175 and the 
gas injector type GI 1083-130. Ar in combination with He was used as an arc gas, and the power supply was $40 \mathrm{~kW}$. The plasma spray deposition parameters of Cu10wt.\%Al powder are shown in Table 1. Before the deposition process, the substrate surfaces were roughened with white aluminum oxide particles of the size $0.7-1.5 \mathrm{~mm}$. Coatings were deposited on the test samples with a thickness of $0.45-0.5 \mathrm{~mm}$.

Table - 1 Plasma spray parameters

Таблица 1 - Параметры плазменного напыления Tabela 1 - Plazma sprej parametri

\begin{tabular}{|l|c|}
\hline Deposition parameters & Values \\
\hline Plasma current, I (A) & 700 \\
\hline Plasma Voltage, U (V) & 35 \\
\hline $\begin{array}{l}\text { Primary plasma gas } \\
\text { flow rate, Ar (I/min) }\end{array}$ & 50 \\
\hline $\begin{array}{l}\text { Secondary plasma gas } \\
\text { flow rate, He (I/min) }\end{array}$ & 12 \\
\hline $\begin{array}{l}\text { Carrier gas } \\
\text { flow rate, Ar (I/min) }\end{array}$ & 5.6 \\
\hline Powder feed rate (g/min) & 50 \\
\hline Stand-off distance (mm) & 100 \\
\hline
\end{tabular}

\section{Results and discussion}

The microhardness and the tensile bond strength of the coating had values characteristic for this type of coatings. The Cu10wt.\%Al Intermetallic coating had an average microhardness of $176 \mathrm{HV}_{0.3}$. The measured average value of microhardness was higher than the value specified by the powder manufacturer - $158 \mathrm{HV}_{0.3}$ (Material Product Data Sheet Aluminum Bronze Thermal Spray Powders Thermal Spray Powder Products Metco 445, 2012, DSMTS-0103.0, Sulzer Metco), which indicates that a large share of micro pores was not present in the coating. This was confirmed by metallographic examinations of the coating layers. The mean value of the tensile bond strength measured on the samples with coated Cu10wt.\%Al was $35 \mathrm{MPa}$. The coating was destroyed at the substrate / coating interface because of good bonding with the substrate. The measured values of the microhardness and the tensile bond strength of Cu10wt.\%Al coatings were correlated with the microstructure of the deposited layers. 
Figures 2 and 3 show the micrographs of a typical microstructure of the plasma spray coating.

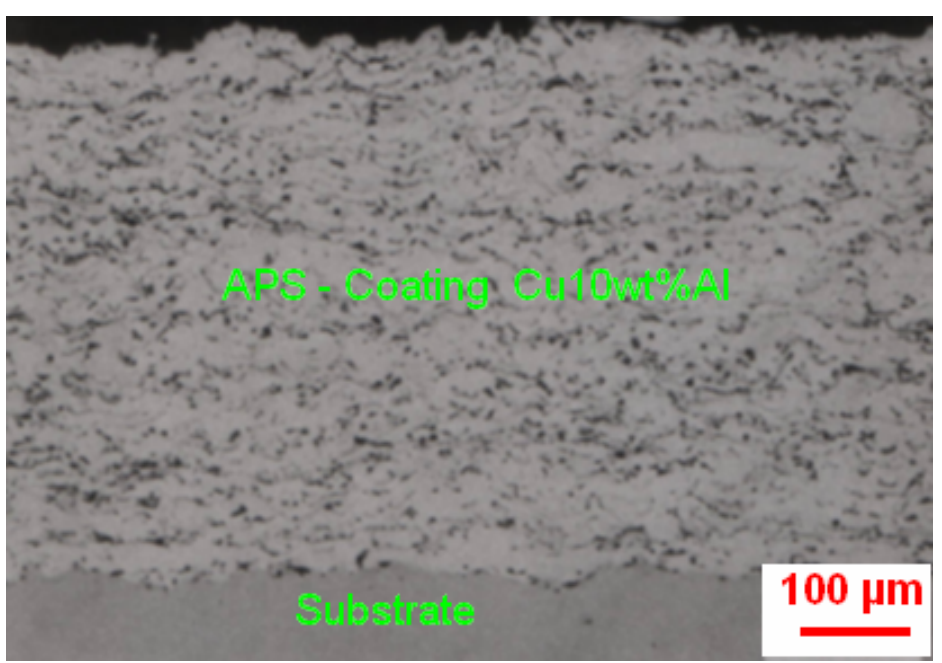

Figure 2 - (OM) Cu10wt.\%Al coating microstructure Puc. 2 - (ОМ) Микроструктура Сu10вес.\%Al покрытия Slika 2 - (OM) Mikrostruktura Cu10tež.\%Al prevlake

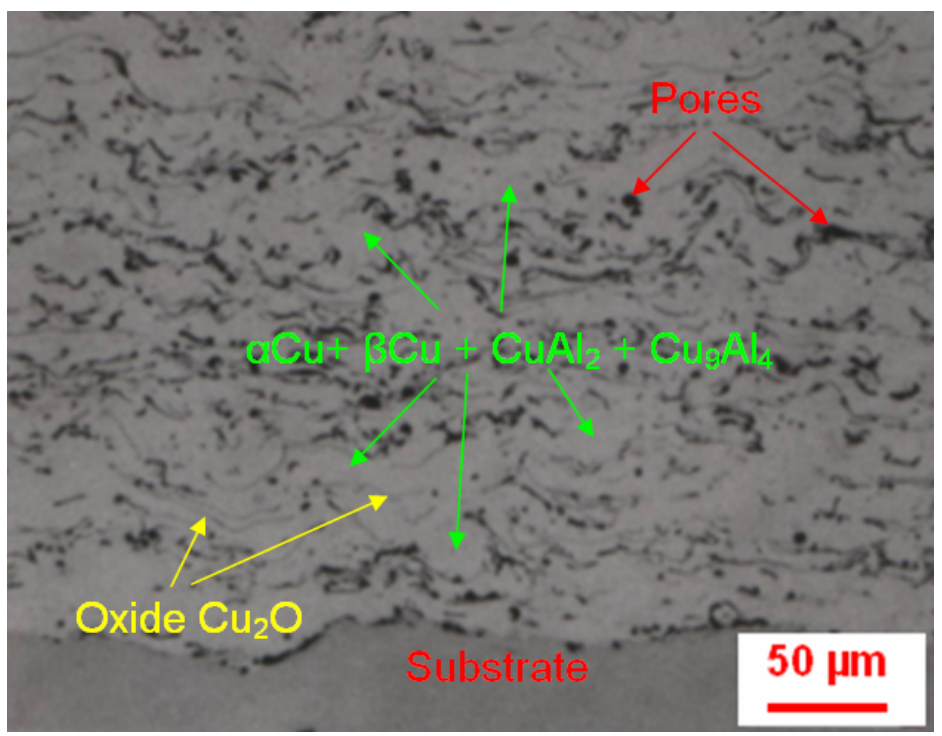

Figure 3 - (OM) Cu10wt.\%Al coating microstructure Puc. 3 - (ОМ) Микроструктура Cu10вес.\%Al покрытия Slika 3 - Mikrostruktura (OM) Cu10tež.\%Al prevlake 
The photomicrographs clearly show the interfaces of coating layers and the substrate. The substrate/coating interface is very clean indicating a very good bonding of the coating with the substrate, which indicates a good substrate surface preparation. Because of good surface preparation, the interface does not show the presence of corundum particles left from roughening, which resulted in good adhesion of the coating with the substrate. At the interface between the substrate and the deposited coating layers, there are no defects such as discontinuities of deposited layers, microcracks, macrocracks, coating peeling and separation from the substrate. Generally, the layers are uniformly deposited on the substrate. The coatings have a lamellar structure, inter-lamellar oxides and interlamellar pores. The microstructure of the coating showed that powder particles are uniformly and homogeneously distributed. Through the coating layers, coarse micro pores, micro cracks and macro cracks cannot be seen. The average share of micro pores in the coating layers was $8 \%$. At a higher magnification, in Figure 3, we can see the light gray lamellae of oxide $\mathrm{Cu}_{2} \mathrm{O}$ with a uniform distribution in the coating (Hang, et al., 2008, pp.416-424), (Li, Sun, 2004, pp.92-101) as well as micro pores in black. In the coating, unmelted powder particles were not detected, which indicates that powder particles had been deposited with the optimal deposition parameters. The Cu10wt.\%Al coating base consists of solid solutions $\alpha-\mathrm{Cu}$ and $\beta-\mathrm{Cu}$ rich in copper containing $\mathrm{CuAl}_{2}$ and $\mathrm{Cu}_{9} \mathrm{Al}_{4}$ intermetallic phases (Hang, et al. 2008, pp.416-424), (Lee, Sun, 2004, pp.92-101).

Figure 4 shows a SEM photomicrograph of the surface of the Cu10wt.\%Al intermetallic coating.

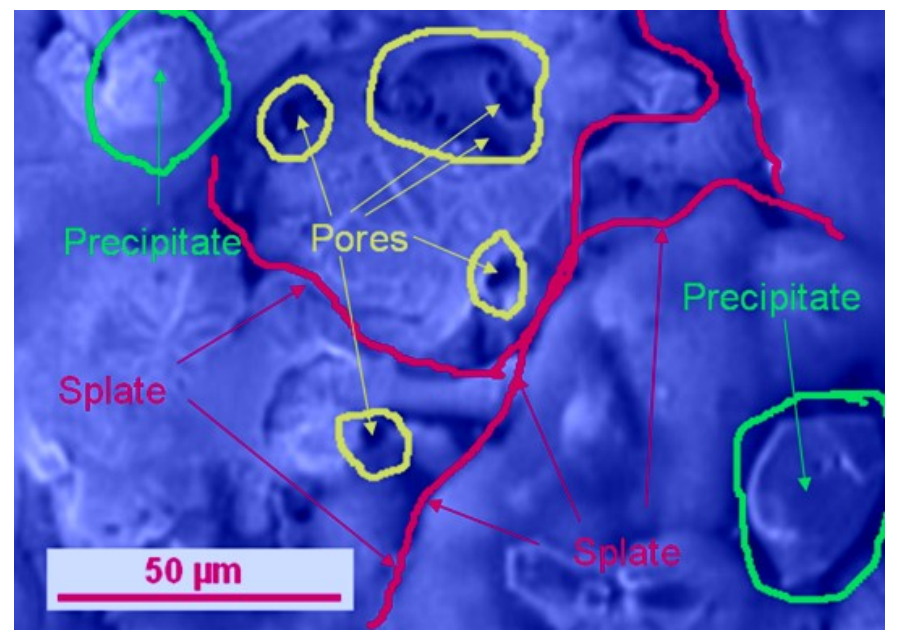

Figure 4-(SEM) Surface morphology of the Cu10wt.\%Al coating Puc. 4 - (SEM) Морфология поверхности Си10вес.\%Al покрытия Slika 4 - (SEM) Morfologija površine Cu10tež. \%Al prevlake 
The analysis of the surface morphology of the Cu10wt.\%Al intermetallic coating shows complete melting and regular melting of powder particles on the previously deposited layer. The red lines in SEM micrographs mark boundaries between the melted particles. The molten powder particles formed thin discs - splates in a collision with the substrate. Thus formed shapes of deposited particles have good cohesive bonding with the previously deposited particles, indicating that the powder particles were deposited with the optimum deposition parameters. Coarse micro pores cannot be seen on the coating surface. SEM micrographs clearly show black micro pores surrounded by yellow color of a size up to $10 \mu \mathrm{m}$. The coating surface shows precipitates formed as a result of the collision of molten droplets with the substrate. At the moment of the collision of molten droplets with the substrate, the ends of molten particles chip and solidify as precipitates in the deposited coating layers.

\section{Conclusion}

In this paper, the APS - atmospheric plasma spray process produced a Cu10wt.\%Al intermetallic coating based on copper with a content of aluminum from 7.0 to $12.0 \mathrm{wt}$.\%Al. The coating deposited on the test samples had a thickness of $0.45-0.5 \mathrm{~mm}$. We analyzed the mechanical properties and the microstructure of the coatings in the deposited state, which led to the following conclusions.

The Cu10wt.\%Al intermetallic coating had good mechanical properties, with a microhardness value of $176 \mathrm{HV}_{0.3}$ which was above the value of $158 \mathrm{HV}_{0.3}$ prescribed by the powder manufacturer. The bond strength was $35 \mathrm{MPa}$. The microstructure is lamellar, consisting of lamellas of oxide $\mathrm{Cu}_{2} \mathrm{O}$ formed by $\mathrm{Cu}$ oxidation in the process of deposition of the powder and inter lamellar pores with an average proportion of $8 \%$.

The base of the Cu10wt.\%Al coating consisted of solid solutions $\alpha$ $\mathrm{Cu}$ and $\beta-\mathrm{Cu}$ rich in copper with $\mathrm{CuAl}_{2}$ and $\mathrm{Cu}_{9} \mathrm{Al}_{4}$ intermetallic phases as a result of the thermal reaction between $\mathrm{Cu}$ and $\mathrm{Al}$ in plasma during melting and deposition.

Applying Cu10wt.\%Al coatings on aircraft parts made of light alloys and exposed to a combination of corrosion and wear has significantly improved the efficiency and reliability of the parts in exploitation and also significantly reduced the costs of repair. 


\section{References}

Alloy Phase Diagrams 1992. ASM International, Metals Park. Volume 3.

Altuncu, E., Iriç, S., \& Ustel, F. 2012. Wear - resistant intermetallic arc spray coatings. Materiali in tehnologije / Materials and technology, 46(2), pp.181-183.

Aluminum Bronze Thermal Spray Powders Thermal Spray Powder Products Metco 445, DSMTS-0103.0 2012. Sulzer Metco. Material Product Data Sheet.

Bartuli, C., Valent, T., Casadei, F., \& Tului, M. 2007. Advanced thermal spray coatings for tribological applications, Proceedings of the Institution of Mechanical Engineers, Part L. Journal of Materials: Design and Applications, 221, pp.175-185.

Hang, C.J., Wang, C.Q., Mayer, M., Tian, Y.H., Zhou, Y., \& Wang, H.H. 2008. Growth Behavior of Cu/Al Intermetallic Compounds and Cracks in Copper Ball Bonds during Isothermal Aging. Microelectronics Reliability, 48, pp.416-424.

Li, C., \& Sun, B. 2004. Microstructure and Property of micro-plasma-sprayed Cu coating. Materials Science and Engineering A, 379, pp.92-101.

Limpichaipanit, A., Watcharapasorn, A., Wirojanupatump, S., \& Jiansirisomboon, S. 2011. Fabrication and Mechanical Properties of Thermal Sprayed Copper-based Coatings. Journal of the Microscopy Society of Thailand, 4(2), pp.123-126.

Mrdak, M., Rakin, M., Medjo, B., \& Bajić, N. 2015. Experimental Study of Insulating Properties and Behaviour of Thermal Barrier Coating Systems in Thermo Cyclic Conditions Materials and Design. Materials and Design, 67, pp.337-343.

Mrdak, M. 2015a. Characteristics of APS and VPS plasma spray processes. Vojnotehnički glasnik / Military Technical Courier, 63(3), pp.137-159.

Mrdak, M. 2015b. Morphology of powder particles produced by spray atomization and other processes. Vojnotehnički glasnik / Military Technical Courier, 63(4), pp.46-67.

Mrdak, M. 2016a. Study of the application of plasma sprayed coatings on the sections of the Astazou III B turbo - jet engine. Vojnotehnički glasnik / Military Technical Courier, 64(1), pp.1-25.

Mrdak, M. 2016b. Properties of the $\mathrm{ZrO}_{2} \mathrm{MgO} / \mathrm{MgZrO}_{3} \mathrm{NiCr} / \mathrm{NiCr}$ triple-layer thermal barrier coating deposited by the atmospheric plasma spray process. Vojnotehnički glasnik / Military Technical Courier, 64(2), pp.411-430.

Sartale, S.D., \& Yoshitake, M. 2010. Investigation of Cu-Al surface alloy formation on Cu substrate. Journal of Vacuum Science \& Technology B, 28, pp.353-360. Whitney.

Standard Practices Manual (PN 582005) 2002. East Hartford, USA: Pratt \&

Vencl, A., Arostegui, S., Favaro, G., Zivic, F., Mrdak, M., Mitrović, S., \& Popovic, V. 2011. Evaluation of adhesion/cohesion bond strength of the thick plasma spray coatings by scratch testing on coatings cross-sections. Tribology International, 44(11), pp.1281-1288.

Vencl, A., Manić, N., Popovic, V., \& Mrdak, M. 2010. Possibility of the abrasive wear resistance determination with scratch tester. Tribology Letters, 37(3), pp.591-604.

Wang, B.Q., \& Seitz, M.W. 2001. Comparison in erosion behavior of ironbase coatings sprayed by three different arc-spray processes. Wear, 250, pp.755-761.

Zhang, Z., Li, D., \& Wang, S. 2006. High Temperature Performance of Arc-sprayed Aluminium Bronze Coatings for Steel. Transactions of Nonferrous Metals Society of China, 16, pp.868-872. 
Михаило Р. Мрдак

Центр исследований и развития А.О. «ИМТЕЛ коммуникации»,

Белград, Республика Сербия

ОБЛАСТЬ: химические технологии

ВИД СТАТЬИ: оригинальная научная статья

ЯЗЫК СТАТЬИ: английский

Резюме:

Плазменное напыление является одним из методов нанесения износостойких покрытий, устойчивых в т.ч. к истеранию, эрозии, кавитации и коррозии. В данной работе описан процесс создания интерметаллического покрытия Cu10вес.\%Al, являющегося надежным кандидатом для применения в трибологических условиях эксплуатации. Преимуществом покрытия данного вида является сочетание низкой стоимости и повышенной стойкости к абразии $в$ различных режимах эксплуатации. Цель данного исследования заключается в изучении механических свойств и структур интерметаллических покрытий Си10вес.\%Аl и развитии эфффективной методологии нанесения покрытия, а также в повышении износостойкости легких сплавов. Многие компоненты сплава меди в коррозийных условиях подвергаются кавитационному и эрозийному разрушению, но своевременная инженерия поверхности соответсвующим покрытием деградирующих слоев, поможет сохранить их. Типичная микроструктура покрытия напылением ламеллярная, с микропорами, несплавленными частицами, межламеллярными оксидами и преципитатами. Испытания механических характеристик покрытия Си10вес.\%Al проводились методом $\mathrm{HV}_{0.3}$ а испытания прочности соединений - методом растяжения. Морфология частиц порошка и поверхности покрытия испытаны методом электронной микрографрии (SEM). Испытания микроструктуры покрытия проведены методом оптической микроскопии, а микропоры исследованы методом оптической микрографии (OM).

Ключевые слова: износ, интерметаллиды, эрозия, коррозия, покрытие, кавитация, Al, абразия. 

NAPRSKANE ATMOSFERSKIM PLAZMA SPREJ POSTUPKOM

\author{
Mihailo R. Mrdak \\ Istraživački i razvojni centar IMTEL Komunikacije a.d., Beograd, \\ Republika Srbija \\ OBLAST: hemijske tehnologije \\ VRSTA ČLANKA: originalni naučni članak \\ JEZIK ČLANKA: engleski
}

\title{
Sažetak:
}

Atmosferski plazma sprej je jedan od postupaka koji se koristi za depoziciju prevlaka otpornih na habanje usled trenja, erozije, kavitacije $i$ korozije. U ovom radu, APS postupkom proizvedena je intermetalna prevlaka Cu10tež.\%Al, koja je pouzdana za primenu u tribološkim okruženjima zbog kombinacije niske cene i izuzetne otpornosti na abraziju pri različitim uslovima rada. Cilj ovoga rada bio je da se izuče mehanička svojstva i struktura intermetalne prevlake Cu10tež.\%Al i razvije efikasan metod za reparaciju i poboljšanje otpornosti lakih legura na habanje. Mnoge komponente od legure bakra imaju tendenciju da se degradiraju zbog korozivne sredine, trenja, erozije $i$ kavitacije. Takve komponente mogu se spasti inženjerstvom površina sa primenom odgovarajućih prevlaka na površinama izloženim degradaciji. Tipična mikrostruktura prevlake za APS postupak je lamelarna u kojoj su prisutne mikropore, neistopljene čestice, međulamelarni oksidi i precipitati. Mehaničke karakteristike prevlake Cu10tež.\%Al ispitane su merenjem mikrotvrdoće slojeva prevlake metodom $\mathrm{HV}_{0.3}$ i čvrstoće spoja metodom ispitivanja na zatezanje. Morfologija čestica praha i površina prevlake analizirana je na skening elektronskom mikroskopu (SEM). Analiza mikrostrukture prevlake urađena je uz korišćenje optičkog mikroskopa, a udeo mikropora određen je analizom mikrofotografija sa optičkog mikroskopa (OM).

Uvod

Atmosferski plazma sprej (APS) jedan je od tehnoloških postupaka koji se koristi za proizvodnju prevlaka debljine između 0,1 i 0,5 mm. Plazma sprej tehnologija je jedna od mogućih rešenja proizvodnje prevlaka na bazi bakra zbog povoljnih troškova proizvodnje $i$ sposobnosti da se proizvedu prevlake na delovima složenih oblika. APS proces uključuje ubacivanje čestica praha u mlaz plazme, njegovo topljenje ili polutopljenje, a zatim ubrzavanje i sudaranje sa podlogom, gde se čestice praha deponuju i formiraju prevlaku (Mrdak, 2015a, pp.137-159), (Mrdak, 2015b, pp.46-67). Mehaničke karakteristike i mikrostruktura prevlaka pod uticajem je velikog broja parametara procesa koji direktno utiču na fazni sastav i sadržaj poroznosti za određeni prah i raspon čestica praha (Mrdak, et al., 2015, pp.337-343), (Mrdak, 2016a, pp.1-25), (Mrdak, 2016b, pp.411-430), 
(Vencl, et al., 2011, pp.1281-1288), (Vencl, et al., 2010, pp.591-604). Bakar je metal koji ima široku primenu u mnogim aplikacijama zbog svoje odlične toplotne i električne provodljivosti. Mehaničke osobine bakra mogu se poboljšati legiranjem, što karakteriše legure bakra. Neke legure bakra, kao što su Cu-Al, Cu-Si i Cu-Al-Fe, koriste se za širu industrijsku primenu, jer su prilično dobri materijali kada je u pitanju otpornost na visoko habanje i koroziju. Legura Cu10tež.\%Al mnogo se upotrebljava u hemijskoj industriji radi velike otpornosti na koroziju. U leguri Cu10tež.\%Al, pored a strukture pojavljuje se i $\beta$ struktura. Prevlaka Cu10tež.\%Al otporna na habanje koristi se na radnim delovima da smanji štetu usled trenja, erozije, kavitacije i korozije (Bartuli, et al., 2007, pp.175-185). Prah Cu10tež.\%Al, oznake Metco 445, jeste mehanički obložena aluminijumska bronza koja pokazuje samovezivanje za substrate za vreme termo-sprej procesa kao rezultat hemijske reakcije obloženih komponenti koji grade intermetalne faze. Prah sadrži aluminijum od 7,0 do 12,0tež.\%Al (Material Product Data Sheet Aluminum Bronze Thermal Spray Powders Thermal Spray Powder Products Metco 445, 2012, DSMTS-0103.0, Sulzer Metco). Prevlake imaju dobru otpornost na trenje i zaribavanje na niskim i umerenim temperaturama i odličnu otpornost na abraziju i kavitaciju. Ispitivanje prevlake Cu10wt.\%Al na abraziono habanje i habanje klizanjem, gde se koristila metoda prsten - na - disku i opterećenje od $150 \mathrm{~g}$ pri brzini klizanja od 4,5 $\mathrm{cm} / \mathrm{s}$ pokazalo je da je abraziono habanje prevlake 0,52 $\mathrm{mgm}^{-1}$, a habanje klizanjem $2,8 \times 10^{-5} \mathrm{~mm}^{3} \mathrm{~m}^{-1}$. Glavni mehanizam habanja prevlake je plastična deformacija (Limpichaipanit, et al., 2011, pp.123-126). Prevlake se lako i odlično obrađuju mašinski. Tipične komponente na kojima se koristi Cu10tež.\%Al prevlaka su: oslonci ležajeva, rukavci hidrauličnih presa, vođice klipova, zaptivači kompresora vazduha, pumpe za vodu, turbinske mlaznice $i$ dr. Prisustvo aluminijuma u bronzi uvećava otpornost prevlake na koroziju usled formiranja tankog kohezivnog površinskog oksida koji deluje kao zaštitni sloj na leguri bogatoj bakrom (Material Product Data Sheet Aluminum Bronze Thermal Spray Powders Thermal Spray Powder Products Metco 445, 2012, DSMTS-0103.0, Sulzer Metco). Da bi se bolje razumeli procesi reakcije koji se dešavaju između Cu i Al za vreme procesa topljenja praha i formiranja intermetalnih faza, neophodno je znati ravnotežni dijagram Cu-Al. U ravnotežnom dijagramu faza Cu-Al postoji pet stabilnih intermetalnih faza, kao što su: $\mathrm{Cu}_{9} A I_{4}, C u_{3} \mathrm{Al}_{2}, C u_{4} A l_{3}, \mathrm{CuAl} i$ $\mathrm{CuAl}_{2}$, sa dva čvrsta rastvora $\mathrm{Cu}(\mathrm{Al})$, koji se često opisuju kao $\alpha-C u$ i Al(Cu) (ASM Handbook, 1992, Volume 3, Alloy Phase Diagrams, ASM International, Metals Park). Istraživanja su pokazala da se u procesu topljenja praha u plazmi, usled reakcije Cu i Al, formiraju različite intermetalne faze kao što su: $\mathrm{CuAl}_{2}, \mathrm{Cu}_{9} \mathrm{Al}_{4}, \mathrm{Cu}_{3} \mathrm{Al}_{2}, \mathrm{Al}_{4} \mathrm{Cu}_{9}$ (Altuncu, et al., 2012, pp.181-183). Glavne intermetalne faze koje utiču na otpornost na habanje prevlake su $\mathrm{Cu}_{9} \mathrm{Al}_{4}$ i $\mathrm{Cu}_{3} \mathrm{Al}_{2}$. Plazma sprej deponovana Cu10tež.\%Al prevlaka ima lamelarnu strukturu, sa prisutnim neistopljenim česticama, precipitatima i interlamelarnim porama. Po autorima (Hang, et al., 2008, pp.416-424), (Li, Sun, 2004, pp.92-101) u mikrostrukturi su prisutne intermetalne faze tipa $\mathrm{CuAl}_{2} i \mathrm{Cu}_{9} \mathrm{Al}_{4}$. Osnovu legure čini čvrsti rastvor $\alpha$-Cu(90,6-100tež.\%Cu) i $\beta$-Cu(85,0-91,5tež.\%Cu). U mikrostrukturi pre- 
vlake nisu prisutne crne oksidne lamerle oksida $\mathrm{Al}_{2} \mathrm{O}_{3}$ ( $\mathrm{Li}$, Sun, 2004, pp.92-101). Prevlake Cu10tež.\%Al sastoje se od svetle faze bakra i tamne faze oksida bakra $\mathrm{Cu}_{2} \mathrm{O}$. Oksid bakra se, pre svega, formira kada je temperatura $\geq 1000^{\circ} \mathrm{C}$ i prisutan kiseonik, što se dešava pri primeni plazma sprej postupka (Hang, et al., 2008, pp.416-424), (Li, Sun, 2004, pp.92-101).

$\cup$ ovom radu plazma sprej postupkom na atmosferskom pritisku deponovana je prevlaka aluminijumske bronze koja sadrži 7,0-12,0 tež.\%Al. Mikrostruktura prevlake je analizirana na svetlosnom mikroskopu i površina prevlake na skening elektronskom mikroskopu. Cilj ovoga rada bio je da se izuče mehanička svojstva i mikrostruktura intermetalne prvlake Cu10tež.\%Al i razvije ekonomski efikasan metod deponovanja intermetalne prevlake za poboljšanje otpornosti pohabanih vazduhoplovnih delova od legura Cu izloženih kombinaciji korozije i habanja.

Materijali i eksperimentalni detalji

Materijal na kojem su deponovani slojevi intermetalne prevlake Cu10tež.\%Al (7,0-12,0tež.\%Al) bio je od nerđajućeg čelika X15Cr13(EN1.4024) u termički neobrađenom stanju. Za proizvodnju Cu10tež.\%Al prevlake upotrebljen je prah firme "Sulzer Metco” sa oznakom Metco 445. Prah je proizveden metodom mehaničkog oblaganja i sferoidizacije na određenu granulaciju gustine $3,1-4,3 \mathrm{~g} / \mathrm{cm}^{3}$. Temperatura topljenja praha je $1040^{\circ} \mathrm{C}$. Za eksperiment se koristio prah koji je imao raspon granulata od 45 do $106 \mu$ m (Material Product Data Sheet Aluminum Bronze Thermal Spray Powders Thermal Spray Powder Products Metco 445, 2012, DSMTS-0103.0, Sulzer Metco).

Ispitivanje mehaničkih karakteristika prevlake Cu10tež.\%Al rađeno je prema standardu Pratt\&Whitney (Turbojet Engine-Standard Practices Manual (PN 582005), 2002, Pratt \& Whitney, East Hartford, USA). Osnove na kojima su deponovani slojevi prevlake za ispitivanje mikrotvrdoće $i$ za procenu mikrostrukture u deponovanom stanju izrađene su od čelika Č.4171 (X15Cr13 EN10027) u termički neobrađenom stanju, dimenzija $70 \times 20 \times 1,5 \mathrm{~mm}$. Osnove za ispitivanje čvrstoće spoja takođe su izrađene od čelika Č.4171(X15Cr13EN10027) u termički neobrađenom stanju, dimenzija $\varnothing 25 \times 50 \mathrm{~mm}$. Mikrotvrdoća slojeva ispitivana je metodom $H_{0.3}$, a čvrstoća spoja ispitivanjem na zatezanje. Merenje mikrotvrdoće izvršeno je u pravcu duž lamela. Urađeno je pet očitavanja vrednosti mikrotvrdoće slojeva u sredini i na krajevima uzoraka od kojih su odbačene dve krajnje vrednosti. Od tri preostale vrednosti prikazana je srednja vrednost. Ispitivanje čvrstoće spoja rađeno je na sobnoj temperaturi sa brzinom zatezanja $1 \mathrm{~cm} / 60 \mathrm{~s}$. Ispitano je pet epruveta od kojih su odbačene dve krajnje vrednosti. Od tri preostale vrednosti prikazana je srednja vrednost čvrstoće spoja. Morfologija čestica praha i površina deponovane prevlake urađena je skening elektronskom mikroskopijom, a mikrostruktura deponovanih slojeva ispitana je na optičkom mikroskopu. Analiza udela mikropora u prevlaci urađena je obradom 5 fotografija na uveličanju 200x. U radu je prikazana srednja vrednost udela mikropora u prevlaci. 
Depozicija Cu10tež.\%Al praha urađena je sa atmosferski plazma sprej sistemom firme „Plasmadyne” i plazma pištoljem SG-100, sa kontrolisanim plazma sprej parametrima. Plazma pištolj SG-100 sastojao se od katode tipa K 1083A-129, anode tipa A 2083-175 i gas injektora tipa GI 1083A-130. Kao lučni gas koristio se Ar u kombinaciji sa He i snaga napajanja do 40kW. Plazma sprej parametri depozicije Cu10wt.\%Al praha prikazani su u tabeli 1. Pre procesa deponovanja površine substrata su hrapavljene česticama belog korunda veličine od 0,7 do 1,5mm. Prevlake su deponovane na ispitnim uzorcima sa debljinama od 0,45 do 0,5mm.

\section{Rezultati i diskusija}

Mikrotvrdoća i zatezna čvrstoća spoja prevlake imale su vrednosti koje su karakteristične za ovaj tip prevlake. Intermetalna prevlaka Cu10tež.\%Al imala je prosečnu vrednost mikrotvrdoće $176 \mathrm{HV}_{0.3}$. Izmerena prosečna vrednost mikrotvrdoće bila je veća od vrednosti koju propisuje proizvođač praha $158 \mathrm{HV}_{0.3}$ (Material Product Data Sheet Aluminum Bronze Thermal Spray Powders Thermal Spray Powder Products Metco 445, 2012, DSMTS-0103.0, Sulzer Metco), što ukazuje na to da u prevlaci nije prisutan veliki udeo mikropora. To su potvrdila metalografska ispitivanja slojeva prevlake. Srednja vrednost zatezne čvrstoće spoja izmerena na uzorcima sa prevlakom Cu10tež.\%Al bila je $35 \mathrm{MPa}$. Prevlaka je razorena na interfejsu supstrat/prevlaka zbog dobrog spoja sa substratom. Izmerene vrednosti mikrotvrdoće i zatezne čvrstoće spoja Cu10tež.\%Al prevlake bile su u korelaciji sa mikrostrukturom deponovanih slojeva. Na mikrofotografijama se jasno uočavaju međugranice spoja slojeva prevlake i substrata. Međugranica između substrata i slojeva prevlake je izuzetno čista, ukazujući na izuzetno dobru vezu slojeva prevlake sa substratom, što govori o dobroj pripremi površine substrata. Zbog dobre pripreme površine substrata na interfejsu nisu prisutni ostaci čestica korunda od hrapavljenja, što se odrazilo na dobru adheziju prevlake sa substratom. Na interfejsu između substrata i deponovanih slojeva prevlake nisu prisutni defekti kao što je diskontinuitet deponovanih slojeva, mikropukotine, makropukotine, ljuštenje $i$ odvajanje prevlaka sa substrata. Generalno, slojevi su ravnomerno deponovani na podlogu. Prevlake imaju lamelarnu strukturu, interlamelarne okside $i$ interlamelarne pore. Mikrostruktura prevlake pokazuje da su čestice praha ravnomerno i homogeno distribuirane. Kroz slojeve prevlake ne uočavaju se grube mikropore, mikropukotine i makropukotine. Prosečan udeo mikropora u slojevima prevlake bio je $8 \%$. Pri većem uveličanju (slika 3) jasno se vide svetlo- sive lamele oksida $\mathrm{Cu}_{2} \mathrm{O}$ sa ravnomernom raspodelom u prevlaci (Hang, et al., 2008, pp.416-424), (Li, Sun, 2004, pp.92-101) i mikropore crne boje. U prevlakama nisu uočene neistopljene čestice praha, ukazujući da su čestice praha deponovane sa optimalnim parametrima depozicije. Osnova prevlake Cu10tež.\%Al sastoji se od čvrstih rastvora $\alpha-C u$ i $\beta-\mathrm{Cu}$ bogatih bakrom u kojima se nalaze intermetalne faze $\mathrm{CuAl}_{2} i$ $\mathrm{Cu}_{9} \mathrm{Al}_{4}$ (Hang, et al., 2008, pp.416-424), (Li, Sun, 2004, pp.92-101). 
Analiza morfologije površine intermetalne prevlake Cu10tež.\%AI pokazuje potpuno topljenje i pravilno razlivanje čestica praha na prethodno deponovani sloj. Na SEM mikrofotografiji crvenom linijom su označene granice između razlivenih čestica. Istopljene čestice praha formirale su tanke diskove - splates u sudaru sa podlogom. Tako formirani oblici deponovanih čestica ostvaruju dobru kohezivnu vezu sa prethodno deponovanim česticama, ukazujući da su čestice praha deponovane sa optimalnim parametrima depozicije. Na površini prevlake se ne uočavaju grube mikropore. Na SEM mikrofotografiji jasno se vide crne mikropore, zaokružene žutom bojom veličine do $10 \mu \mathrm{m}$. Na površini prevlake uočavaju se precipitati koji su nastati kao posledica sudara istopljenih kapi sa substratom. U trenutku sudara istopljenih kapi sa podlogom dolazi do odlamanja krajeva istopljenih čestica, koji očvršćavaju kao talog u deponovanim slojevima prevlake.

\section{Zaključak}

$U$ radu je atmosferskim plazma sprej procesom (APS) proizvedena intermetalna prevlaka Cu10tež.\%Al na bazi bakra sa sadržajem aluminijuma od 7,0 do 12,0tež.\%Al. Prevlake deponovane na ispitnim uzorcima bile su debljine od 0,45 do 0,5 mm. Analizirane su mehaničke karakteristike i mikrostrukture prevlaka u deponovanom stanju, na osnovu čega se došlo do određenih zaključaka.

Intermetalna prevlaka Cu10tež.\%Al imala je dobre mehaničke osobine, čija je mikrotvrdoća od $176 H_{0.3}$ bila iznad vrednosti 158 $H_{0.3}$ koju propisuje proizvođač praha, i čvrstoću spoja od $35 \mathrm{MPa}$. Mikrostruktura prevlake je lamelarna, a sastoji se od oksidnih lamela $\mathrm{Cu}_{2} \mathrm{O}$ formiranih oksidacijom $\mathrm{Cu}$ u procesu depozicije praha i interlamelarnih pora sa prosečnim udelom od 8\%. Osnova Cu10tež.\%Al prevlake sastoji se od čvrstih rastvora $\alpha-C u$ i $\beta$-Cu bogatih bakrom u kojima se nalaze intermetalne faze $\mathrm{CuAl}_{2}$ i $\mathrm{Cu}_{9} \mathrm{Al}_{4}$ nastale kao rezultat termičke reakcije između Cu i Al u plazmi u toku procesa topljenja i deponovanja.

Primenom Cu10tež.\%Al prevlake u remontu na vazduhoplovnim delovima od lakih legura izloženih kombinaciji korozije $i$ habanja znatno se poboljšala efikasnost i pouzdanost rada delova u eksploataciji $i$ smanjili se troškovi remonta.

Ključne reči: habanje, intermetali, erozija, korozija, prevlaka, kavitacija, Al, abrazija.

Paper received on / Дата получения работы / Datum prijema članka: 09. 04. 2016. Manuscript corrections submitted on / Дата получения исправленной версии работы / Datum dostavljanja ispravki rukopisa: 20. 04. 2016.

Paper accepted for publishing on / Дата окончательного согласования работы / Datum konačnog prihvatanja članka za objavljivanje: 22. 04. 2016. 
(C) 2016 The Author. Published by Vojnotehnički glasnik / Military Technical Courier

ᄂ

(www.vtg.mod.gov.rs, втг.мо.упр.срб). This article is an open access article distributed under the terms and conditions of the Creative Commons Attribution license

(http://creativecommons.org/licenses/by/3.0/rs/).

(c) 2016 Автор. Опубликовано в "Военно-технический вестник / Vojnotehnički glasnik / Military Technical Courier" (www.vtg.mod.gov.rs, втг.мо.упр.срб). Данная статья в открытом доступе и распространяется в соответствии с лицензией "Creative Commons"

(http://creativecommons.org/licenses/by/3.0/rs/).

(C) 2016 Autor. Objavio Vojnotehnički glasnik / Military Technical Courier (www.vtg.mod.gov.rs втг.мо.упр.срб). Ovo je članak otvorenog pristupa i distribuira se u skladu sa Creative Commons licencom (http://creativecommons.org/licenses/by/3.0/rs/). 